\title{
Harvest Interval Has Greater Effect on Periderm Maturity and Storage Quality of Early-maturing, Tablestock Potato than Nitrogen Rate
}

\author{
Mildred N. Makani, Steven A. Sargent ${ }^{1}$, Lincoln Zotarelli, \\ and Donald J. Huber \\ Department of Horticultural Sciences, University of Florida, P.O. Box 110690, \\ Gainesville, FL 32611 \\ Charles A. Sims \\ Department of Food Science and Human Nutrition, University of Florida, \\ P.O. Box 110370, Gainesville, FL 32611
}

Additional index words. early potato, drip irrigation, fertigation, potato storage, subtropical vegetable production, tuber quality, periderm, dry matter content, ascorbic acid content

\begin{abstract}
Early-maturing potato cultivars (Solanum tuberosum L.) grown in many subtropical and tropical regions are typically packed and shipped without curing. The objective of this study was to evaluate two early-maturing potato cultivars ('Fabula' and 'Red LaSoda') grown under four nitrogen fertilizer (NF) rates and harvested at three intervals after vine kill for effects on tuber physical and compositional quality at harvest and during storage. NF was applied through fertigation $\left(0,112,224\right.$, or $\left.336 \mathrm{~kg} \cdot \mathrm{ha}^{-1}\right)$ and compared with granular NF application $\left(224 \mathrm{~kg} \cdot \mathrm{ha}^{-1}\right)$. The tubers were harvested weekly after vine kill (H1, H2, and $\mathrm{H3})$ then evaluated for quality at 7 and 14 days during storage at $10{ }^{\circ} \mathrm{C} / 80 \%$ to $85 \%$ relative humidity (RH). 'Fabula' tubers from $\mathrm{H} 1$ had the highest cumulative weight loss $(3.6 \%)$ after 14 days of storage (season 1 ), while those from both $\mathrm{H} 1$ and $\mathrm{H} 2$ were highest $(4.4 \%)$ in season 2 , regardless of $\mathrm{NF}$ application method or rate. Tuber firmness increased by 1.5 newtons $(N)$ for tubers from $H 1$ after 7 days storage, and again by $0.76 \mathrm{~N}$ after 14 days for tubers from $\mathrm{H} 2$ and $\mathrm{H3}$. Periderm dry matter content (DMC) for $\mathrm{H} 1$ tubers increased to $13.9 \%$ after 7 days, regardless of fertilizer treatment, in contrast to those from $\mathrm{H} 2$ or $\mathrm{H} 3$ where DMC remained constant throughout storage $(10.6 \%$ and $11.4 \%$, respectively). For 'Red LaSoda', cumulative weight loss in season 1 for $\mathrm{H} 1$ tubers was $2.2 \%$ after 14 days storage, whereas that for $\mathrm{H2}$ and $\mathrm{H3}$ tubers averaged $0.7 \%$; this trend was similar for season 2. Periderm DMC significantly increased with increased storage time; that for $\mathrm{H} 2$ tubers was highest $\mathbf{( 1 9 . 6 \% )}$ after 14 days. In both cultivars, tuber ascorbic acid content (AAC), soluble solids content (SSC), and total titratable acidity (TTA) remained constant throughout the 14day storage period. Periderm maturity of 'Fabula' and 'Red LaSoda' potatoes had a greater effect on tuber physical and compositional quality during storage than the fertilizer rates or application methods. Fertigation at NF rates of 112, $224 \mathrm{or} 336 \mathrm{~kg} \cdot \mathrm{ha}^{-1}$ was comparable with conventional granular NF application for growing high-quality tubers with acceptable postharvest life. Growing tubers at $112 \mathrm{~kg} \cdot \mathrm{ha}^{-1}$ nitrogen via fertigation has the potential to reduce both irrigation water usage and fertilizer runoff during the production cycle.
\end{abstract}

Potato (Solanum tuberosum L.) tubers continue active metabolism after harvest and require appropriate storage conditions to minimize losses that can arise from these

\footnotetext{
Received for publication 22 Feb. 2017. Accepted for publication 7 Aug. 2017.

We thank the Florida Department of Agriculture and Consumer Services (FDACS) for partial funding of this project. We also acknowledge the support of the North Florida Potato Growers Association, the University of Florida/IFAS Hastings Research and Extension Center and the UF Horticultural Sciences Department. We appreciate the field and laboratory assistance of Joel Reyes-Cabrera, Adrian Berry and Scott Taylor. ${ }^{1}$ Corresponding author. E-mail: sasa@ufl.edu.
}

physiological processes (Kumar et al., 2004). One key factor determining storability of tubers is harvest maturity, classified as physical, physiological, and chemical maturity (Bussan, 2003). Tablestock potatoes reach harvest maturity when the tuber periderm adheres firmly to the underlying cell layers, the point known as skin-set (Lulai and Orr, 1993). Early-season tablestock cultivars are often grown as a spring crop to meet an early market window with high prices; however, they are typically harvested 90-120 d after planting (DAP) at which point the periderm is minimally mature and easily removed (UNECE Standard FFV-52, 2011). Greater quantitative and qualitative losses are associated with storage of immature tubers (Burton,
1989) whereas tubers harvested from senescent plants are physically more mature (Braue et al., 1983). For this reason, tablestock potato vines are killed before harvest to promote periderm physical maturity ("skin-set"), thereby reducing skinning or scuffing during mechanical harvest and subsequent handling operations (Zotarelli et al., 2016b).

Water and nitrogen availability during plant growth can affect leaf growth and carbon partitioning, and subsequently the biochemical process involved in tuber skinset (Tyner et al., 1997). Northeast Florida accounts for the majority of the state's spring potato production, characterized by fine sandy soils with low water-holding capacity and low organic matter content (Manrique, 1993). Heavy and erratic rainfalls commonly experienced in such subtropical growing regions can cause nutrient leaching from the root zone, further decreasing available nitrogen (Papadopoulos, 1988). Acceptable tuber yields and quality are also dependent on the placement and timing of NF (Westermann et al., 1988).

The current grower practice in northeast Florida is band application of granular NF at preplant ( $\approx 30 \mathrm{~d}$ before planting), at plant emergence (25 DAP), and at the onset of tuber initiation (Rens et al., 2015). There is rapid nitrogen uptake 45-65 DAP (Zotarelli et al., 2014, 2015b), during which time the risk of leaching is also high. Seepage irrigation is the primary method used in this region and requires maintenance of a high water table. This method also has the potential for increased nutrient leaching and runoff, and has raised important ecological and humanhealth concerns in this growing region, where groundwater is the source of drinking water for most of the residents. By contrast, fertigation delivers dissolved fertilizer through drip tapes that increases water and nutrient use efficiency by precisely applying water and nutrients to the plant root zone. ReyesCabrera et al. (2014) also reported significant decreases in tuber physiological disorders for early-maturing potatoes grown using fertigation.

A companion study of early-maturing, tablestock potatoes grown in sandy soils found that fertigation obtained maximum yields by applying nitrogen at rates 224 $273 \mathrm{~kg} \cdot \mathrm{ha}^{-1}$ (Makani et al., 2015). However, excess NF negatively affects plant and tuber growth by promoting excessive vine growth and by delaying tuber periderm maturation in the field, leading to higher weight loss (Dahlenburg et al., 1990), higher disease incidence (Jablonski, 2006), decreased phytochemical content (Zhang et al., 1997), and low or elevated starch content (Bombik et al., 2002). It is important to note that these studies were conducted using medium-to-late season cultivars that have more mature tuber periderm at harvest because of a longer growing season (up to $180 \mathrm{~d}$ ). Consequently, adoption of NF recommendations based on these cultivars could potentially cause significant storage losses to the more perishable, early-maturing potato cultivars. 


\begin{tabular}{|c|c|c|c|c|c|}
\hline \multirow[b]{3}{*}{ Harvest interval $^{\mathrm{z}}$} & \multicolumn{5}{|c|}{ Pulp dry matter content (\%) } \\
\hline & \multicolumn{5}{|c|}{ Fertilizer treatment $^{\mathrm{y}}$} \\
\hline & $\mathrm{F}-0$ & F-112 & F-224 & F-336 & G-224 \\
\hline$\overline{\mathrm{H} 1}$ & $16.8 \mathrm{aA}^{\mathrm{x}}$ & $14.7 \mathrm{aAB}$ & $13.8 \mathrm{aB}$ & $14.2 \mathrm{aAB}$ & $14.6 \mathrm{aAB}$ \\
\hline $\mathrm{H} 2$ & $13.3 \mathrm{bA}$ & $14.3 \mathrm{aA}$ & $14.1 \mathrm{aA}$ & $14.1 \mathrm{aA}$ & $14.6 \mathrm{aA}$ \\
\hline $\mathrm{H} 3$ & $13.1 \mathrm{bA}$ & $14.3 \mathrm{aA}$ & $14.7 \mathrm{aA}$ & $14.5 \mathrm{aA}$ & $15.0 \mathrm{aA}$ \\
\hline
\end{tabular}

${ }^{\mathrm{z}}$ Harvest intervals: $\mathrm{H} 1, \mathrm{H} 2, \mathrm{H} 3=1,2$, or 3 weeks after vine kill, respectively.

${ }^{\mathrm{y}}$ Fertilizer rates of F-0, F-112, F-224, and F-336 = fertigation rates of $0,112,224$, or $336 \mathrm{~kg} \cdot$ ha $^{-1}$, respectively. G-224 = granular application at $224 \mathrm{~kg} \cdot$ ha $^{-1}$.

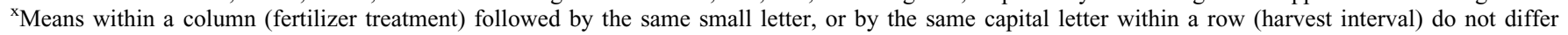
significantly according to Tukey's range probability test $(P<0.05)$.

Table 2. Effects of nitrogen fertilizer method of application and rate on initial soluble solids content (SSC), total titratable acidity (TTA), and $\mathrm{pH}$ content of 'Fabula' tubers (seasons 1 and 2 combined).

\begin{tabular}{lccc}
\hline Fertilizer treatment & SSC (\%) & TTA (\%) & pH \\
\hline F-0 & $2.73 \mathrm{~b}^{\mathrm{y}}$ & $0.12 \mathrm{~b}$ & $2.70 \mathrm{c}$ \\
F-112 & $3.35 \mathrm{~b}$ & $0.13 \mathrm{ab}$ & $3.47 \mathrm{~b}$ \\
F-224 & $3.85 \mathrm{ab}$ & $0.15 \mathrm{a}$ & $3.88 \mathrm{ab}$ \\
F-336 & $4.13 \mathrm{a}$ & $0.14 \mathrm{a}$ & $4.02 \mathrm{a}$ \\
G-224 & $4.15 \mathrm{a}$ & $0.15 \mathrm{a}$ & $4.13 \mathrm{a}$
\end{tabular}

${ }^{\mathrm{z}}$ Fertilizer rates of F-0, F-112, F-224, and F-336 $=$ fertigation rates of $0,112,224$, or $336 \mathrm{~kg} \cdot \mathrm{ha}^{-1}$, respectively. G-224 = granular application at 224 $\mathrm{kg} \cdot \mathrm{ha}^{-1}$.

${ }^{\mathrm{y}}$ Means within each column followed by the same small letter do not differ significantly according to Tukey's range probability test $(P<0.05)$.

The objective of this present work was to determine the effect of growing two commercially important, early-maturing potato cultivars using two NF application methods, four NF rates, and three harvest intervals after vine killing on selected tuber quality and nutritional value parameters at harvest and during simulated commercial storage.

\section{Materials and Methods}

Experimental site and field layout. Field trials were conducted at the UF/IFAS Hastings Agricultural Extension Center, Cowpen Branch Facility, Hastings, FL (29.7167 N, $81.5083 \mathrm{~W}$ ) during Spring 2013 (season 1) and 2014 (season 2). The experiment was laid out as a completely randomized design with treatments in a split-plot design; NF rates were assigned to the main plots and potato cultivars to the sub-plots. The field $(79 \mathrm{~m}$ by $18 \mathrm{~m}$ ) was configured with row spacing = $1.04 \mathrm{~m}$ and hill height $=0.35 \mathrm{~m}$, then subdivided into 32 plots $(7.3 \mathrm{~m}$ each; four plots/treatment).

Two widely grown, early-maturing tablestock potato cultivars, 'Fabula' and 'Red LaSoda', were selected for this study (Source: Maine Farmer's Exchange, Presque Isle, ME). Both cultivars have potential for high yields and are well suited for production in the southeastern United States. 'Fabula' has a light-tan, smooth periderm, oblong shape and yellow pulp; it is vine killed about $87 \mathrm{~d}$ from planting (Mwatuwa, et al., 2017). 'Red LaSoda' has deep-red periderm, deep eyes and white pulp; it is vine killed from 86 to 100 DAP (Zotarelli et al., 2016a). Each cultivar was hand-planted $(20-\mathrm{cm}$ in-row spacing and 15-cm depth) over two spring seasons, on 28 Jan. 2013 and on 29 Jan. 2014. The crop was irrigated using surface drip irrigation, where drip lines (16-mm inner diameter, 8-mm thickness, and 20-cm emitter spacing) with a flow rate of $500 \mathrm{~L} \cdot \mathrm{h}^{-1} 100 \cdot \mathrm{m}^{-1}$ (RO-DRIP; John Deere Water, Moline, IL) were placed $5 \mathrm{~cm}$ above the seed piece after planting. Irrigation commenced 38 and 30 DAP in seasons 1 and 2, respectively; daily irrigation volume, based on calculated crop evapotranspiration, was split into three to four irrigation events, and adjusted according to precipitation received.

For the fertigation treatments, granular ammonium nitrate fertilizer (34-0-0) was completely dissolved in water and injected into the drip system, at four rates $(0,112,224$, and $336 \mathrm{~kg} \cdot \mathrm{ha}^{-1}$; F-0, F-112, F-224, and F336 , respectively). Total NF for each fertigation treatment was split and applied over 5 weeks starting 45 DAP. NF amount at each split application corresponded to projected crop nitrogen requirements, which were based on crop growth stage. The granular NF treatment was based on the recommended rate of $224 \mathrm{~kg} \cdot \mathrm{ha}^{-1}(\mathrm{G}-224)$ and banded and incorporated into the soil at plant emergence and again when plants were $15-20 \mathrm{~cm}$ long. Both treatment methods received phosphorus $\left(112 \mathrm{~kg} \cdot \mathrm{ha}^{-1}\right)$ and potassium $\left(168 \mathrm{~kg} \cdot \mathrm{ha}^{-1}\right)$ fertilizers applied in granular form at preplant; an additional side-dress of potassium (140 $\mathrm{kg} \cdot \mathrm{ha}^{-1}$ ) was applied at plant emergence. In addition, weeds, insects, and diseases were managed using standard practices for the region (Zotarelli et al., 2015a).

Plant vine kill and tuber harvest intervals. Irrigation was stopped 2 weeks before vine kill (91 and 98 DAP in 2013 and 2014, respectively) which involved a single application of the chemical desiccant glufosinate ammonium (Rely ${ }^{\circledR} 280$ Herbicide; Bayer Crop Science, Research Triangle Park, NC) applied at a rate of $1535 \mathrm{~mL} \cdot \mathrm{ha}^{-1}$. Plots were manually harvested weekly for 3 weeks after vine kill $(\mathrm{H} 1, \mathrm{H} 2$, and $\mathrm{H} 3)$; tubers were placed in mesh poly bags and transported about 90 min to the Postharvest Horticulture Laboratory at the University of Florida, Gainesville, for storage and analysis.

Storage test quality analysis. Averagesized tubers (150-200 g) from each NF treatment and field plot replicate $(n=4)$ were carefully sorted to remove defects, handwashed under flowing tap water, fan-dried (about $30 \mathrm{~min}$ ), and stored in mesh poly bags $(n=\approx 50$ tubers $/$ bag $)$ under simulated commercial conditions of $10{ }^{\circ} \mathrm{C}, 80 \%$ to $85 \%$ RH. Tuber $(n=56)$ quality from each fertilizer treatment and each harvest interval was evaluated at harvest and after 7 and $14 \mathrm{~d}$ of storage.

Weight loss was determined at each evaluation on a fresh weight basis. Firmness measurements were made on longitudinal slices derived from central tuber region (20-mm thick, 1 slice/tuber), using a TA HD Plus Texture Analyzer Machine (Texture Technologies Corp, Scarsdale, NY) equipped with a 50-N load cell. Each slice was laid flat and punctured at the center (pith) to 4-mm depth using a convex-tip probe (4-mm diameter) at a loading rate of 2 $\mathrm{mm} \cdot \mathrm{s}^{-1}$ and bioyield force was recorded. Dry matter content (wet weight basis) was determined from a $20-\mathrm{mm}$ thick longitudinal slice, separated into periderm and pulp tissue, and dried at $65^{\circ} \mathrm{C}$ for $48 \mathrm{~h}$.

Three, 20-mm thick, longitudinal slices (one per replicate tuber per plot), were separated into periderm and pulp tissue. Pulp tissue was pureed in a Waring blender for $1 \mathrm{~min}$, the slurry centrifuged ( $20 \mathrm{~min} ; 15,000 \times$ $g_{\mathrm{n}} ; 4{ }^{\circ} \mathrm{C}$ ) using a Beckman model J2-21 centrifuge (Beckman Coulter Inc., Fullerton, CA), filtered through cheesecloth and the supernatant used for chemical analyses.

Soluble solids content was measured using a temperature-compensated digital refractometer (model ABBE Mark II; Cambridge Instruments Inc., Depew, NY) and expressed as percent fresh weight basis. Total titratable acidity and $\mathrm{pH}$ were determined from $3 \mathrm{~mL}$ of the supernatant, diluted with 50 $\mathrm{mL}$ deionized water. The mixture was filtered and titrated with $0.1 \mathrm{~N}$ sodium hydroxide solution to an endpoint of $\mathrm{pH}$ 8.2. Total titratable acidity was calculated using the amount of $0.1 \mathrm{~N}$ sodium hydroxide (in $\mathrm{mL}$ ) multiplied by the conversion factor for malic acid $(0.067)$, the predominant acid in potato (Ranganna, 1986). Ascorbic acid content was measured from $2 \mathrm{~g}$ of separated periderm and pulp tissues, using the AOAC (1984) procedure for the spectrophotometric determination of AAC (absorbance at $\lambda=540 \mathrm{~nm}$ ). For more details, see Makani (2014).

Statistical analysis. Statistical analysis of each variable collected was performed using the general linear mixed model (PROC GLIMMIX) of SAS 9.3 (SAS Institute Inc., Cary, NC). An analysis of variance was performed separately for each cultivar to determine significant treatment effects for growing season, NF method of application and rate, 


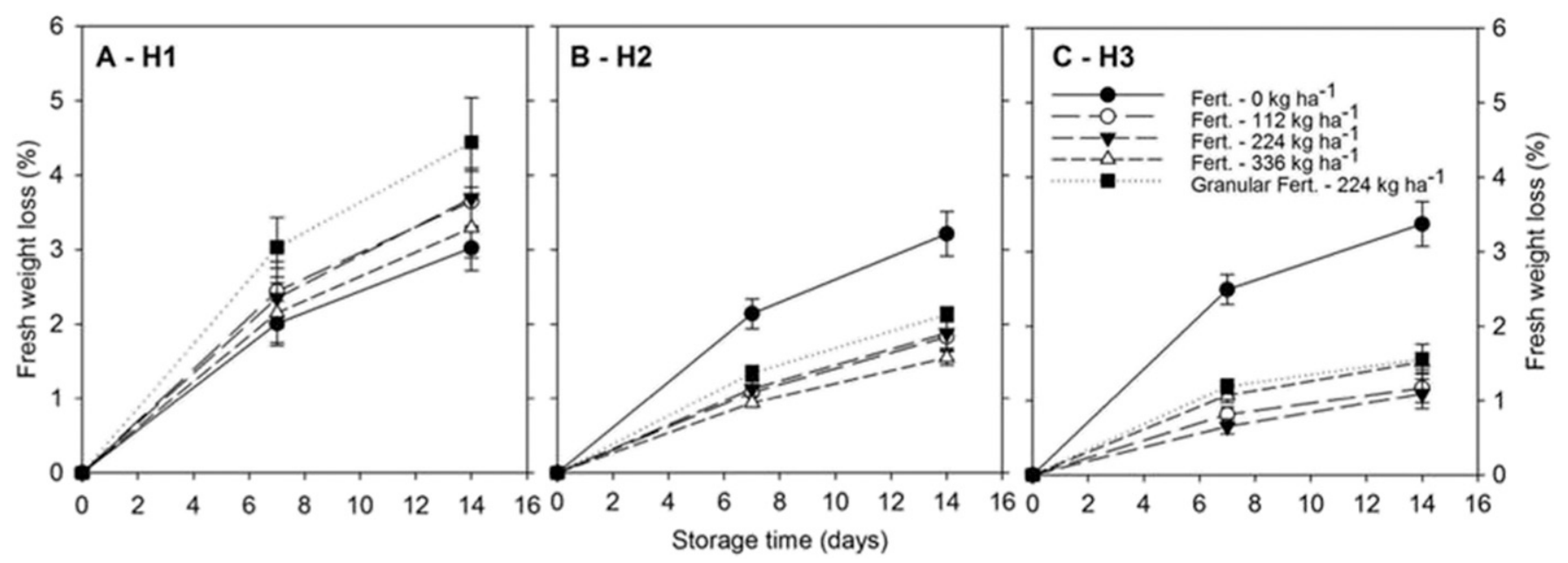

Fig. 1. Effects of $\mathrm{N}$ fertilizer method of application, rate, harvest interval, and storage period on fresh weight loss of 'Fabula' tubers during $14 \mathrm{~d}$ storage at $10{ }^{\circ} \mathrm{C}$, $80 \%$ to $85 \%$ relative humidity (season 1). Fertilizer treatments: F- 0 , F-112, F-224, F-336 $=0,112,224$, or $336 \mathrm{~kg}^{-h^{-1}}$ of N applied as fertigation, respectively; $\mathrm{G}-224=224 \mathrm{~kg} \cdot \mathrm{ha}^{-1}$ of N applied in granular form. Harvest intervals: H1, H2, H3 = 1, 2, or 3 weeks after vine kill, respectively. Error bars represent standard error at the $95 \%$ confidence interval.

and harvest interval. Treatment means were separated using Tukey's range probability test with $95 \%$ confidence limits.

\section{Results and Discussion}

\section{Potato quality at harvest}

There were dramatic differences in rainfall amount and timing between the two seasons. Season 1 had a cumulative rainfall of $454 \mathrm{~mm}$; however, $56 \%$ (254 mm) of the total seasonal rainfall fell during the 3 -week harvest period, with the majority falling just before H1. Rainfall in season 2 was significantly lower (394 mm), and the harvest period was quite dry, with only $9 \%(35 \mathrm{~mm})$ falling during that time.

'Fabula'. At harvest, tuber firmness $(11.9 \mathrm{~N})$ and periderm DMC $(10.9 \%)$ were unaffected by fertilizer treatment, harvest interval, or growing season (data not shown). A previous study using the same NF rate (224 $\mathrm{kg} \cdot \mathrm{ha}^{-1}$ ) with drip irrigation reported higher pulp firmness for 'Fabula' and 'Red LaSoda' potatoes at $\mathrm{H} 1(18-24 \mathrm{~N})$, but lower values for $\mathrm{H} 2$ and $\mathrm{H} 3(13-14 \mathrm{~N})$, similar to those in this study; periderm DMC was also similar to the present study (Makani et al., 2015). With regard to pulp DMC, in season 1 the average for all harvest intervals was $14.1 \%$ (data not shown). However, in the drier season 2 and only for H1, pulp DMC from the F-0 treatment was higher $(16.8 \%)$ than that from the F-224 treatment $(13.8 \%)$ (Table 1). Porter and Sisson (1993), studying late-maturing cultivars, reported that increased NF rate negatively affected tuber dry matter accumulation (periderm and pulp tissues were combined). These authors attributed this difference to the plant diverting more nitrogen to vegetative growth than to tuber growth and development. However, in the current study, there was no clear correlation between fertilizer rate and DMC other than that observed for the single occurrence for tubers grown with $\mathrm{F}-0$ or $\mathrm{F}-224$ rates at $\mathrm{H} 1$.
Tuber SSC, TTA, and pH generally increased with increased fertilizer rate, independent of harvest interval or growing season (Table 2). Tubers grown under the fertigation treatments F-0 or F-112 had a significantly lower SSC $(3.04 \%)$ than under F-336 or the granular treatment G-224 (average 4.14\%). Tuber TTA followed a similar pattern; tubers from the fertigation treatment F-0 had a significantly lower content of $0.12 \%$, compared with $0.15 \%$ with F224, F-336, or G-224. The lowest $\mathrm{pH}$ of 2.7 was for tubers grown with F-0, whereas that for tubers from the other fertilizer treatments ranged from $\mathrm{pH} 3.47-$ 4.13 .

NF supply affects the concentration of sucrose, which is the primary component of SSC in potato tubers (Halford et al., 2012) and the major transport form of photoassimilates from source to sink organs (Zrenner et al., 1995). In the current study, delayed periderm development under high $\mathrm{N}$ rates likely accounted for higher SSC, similar to findings in late-maturing cultivars (Iritani and Weller, 1973). The $\mathrm{pH}$ index determines deterioration potential by fermentation and enzymatic activity; maximum activity of invertase (sucrose breakdown) and phosphorylase (starch breakdown) enzymes occurs at pH 4.7 and 5.5, respectively (Pressey, 1966). Therefore, the higher $\mathrm{pH}$ for tubers from $\mathrm{F}$ 224, F-336, and G-224 (average 4.04) was indicative of a higher tendency to accumulate sugar over starch.

Harvest interval had the greatest effect on tuber AAC, which generally decreased as harvest interval increased; there was no effect because of fertilizer treatment or growing season. Tubers harvested at $\mathrm{H} 1$ had the highest periderm AAC $(17.4 \mathrm{mg} / 100 \mathrm{~g})$, decreasing to $13.2 \mathrm{mg} / 100 \mathrm{~g}$ at $\mathrm{H} 2$ and $\mathrm{H} 3$. Similarly, pulp AAC was $24.4 \mathrm{mg} / 100 \mathrm{~g}$ at $\mathrm{H} 1$ and 18.1 $\mathrm{mg} / 100 \mathrm{~g}$ at $\mathrm{H} 2$ and $\mathrm{H} 3$ (data not shown). Previous results showed a similar trend for 'Fabula' and 'Red LaSoda' potatoes, although actual values were higher for the

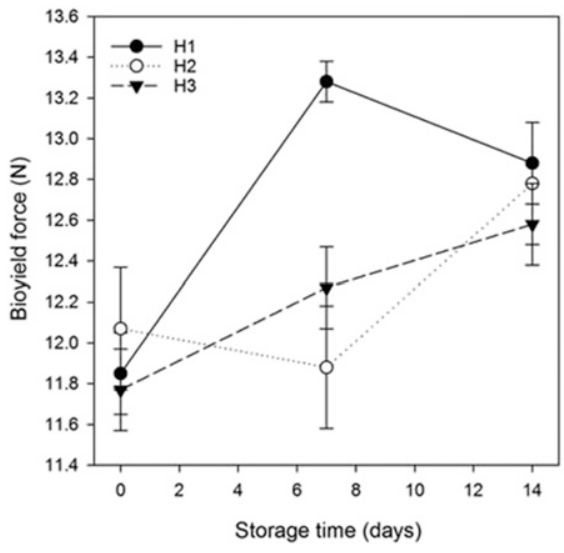

Fig. 2. Effects of harvest interval and storage period on firmness of 'Fabula' tubers' during $14 \mathrm{~d}$ storage at $10{ }^{\circ} \mathrm{C}, 80 \%$ to $85 \%$ relative humidity (seasons 1 and 2 combined). Harvest intervals: $\mathrm{H} 1, \mathrm{H} 2, \mathrm{H} 3=1,2$, or 3 weeks after vine kill, respectively. Error bars represent standard error at the $95 \%$ confidence interval.

respective harvest intervals (Makani et al., 2015). The literature is replete with studies showing a decline in tuber AAC of mediumto-late-maturing cultivars when harvest is delayed (Perkins, 1993; Shekhar et al., 1978). This reduction in biosynthesis of $\mathrm{AAC}$ was attributed to vine death and natural senescence.

'Red LaSoda'. In season 1, tuber firmness at harvest was unaffected by NF treatment; at $\mathrm{H} 1$ and $\mathrm{H} 2$ firmness was $13.1 \mathrm{~N}$, decreasing slightly but significantly to $11.8 \mathrm{~N}$ at $\mathrm{H} 3$ (data not shown). In season 2 , the drier harvest period, tuber firmness was unaffected by fertilizer treatment or harvest interval and averaged $13.1 \mathrm{~N}$ (data not shown).

In season 1 only, pulp DMC at harvest was higher in tubers grown under F-0 (15.3\%), compared with those from the other fertilizer treatments $(13.7 \%)$ (data not shown); for 'Fabula', pulp DMC was higher for F-0 tubers 
Table 3. Effects of $\mathrm{N}$ fertilizer method of application and rate, harvest interval and storage period on tuber periderm dry matter content of 'Fabula' during $14 \mathrm{~d}$ storage at $10{ }^{\circ} \mathrm{C}, 80 \%$ to $85 \%$ relative humidity (seasons 1 and 2 combined).

\begin{tabular}{|c|c|c|c|c|c|c|}
\hline \multirow{2}{*}{ Harvest interval $^{\mathrm{z}}$} & \multirow{2}{*}{ Storage period $(\mathrm{d})$} & \multicolumn{5}{|c|}{ Periderm dry matter content $(\%)$} \\
\hline & & \multicolumn{5}{|c|}{ Fertilizer treatment ${ }^{y}$} \\
\hline \multirow[t]{2}{*}{ H1 } & 0 & $10.9 \mathrm{bA}^{\mathrm{x}}$ & $11.1 \mathrm{bA}$ & $10.4 \mathrm{bA}$ & $10.8 \mathrm{bA}$ & $11.3 \mathrm{bA}$ \\
\hline & 14 & $14.4 \mathrm{aA}$ & $14.3 \mathrm{aA}$ & $11.4 \mathrm{bB}$ & $14.1 \mathrm{aA}$ & $11.1 \mathrm{bB}$ \\
\hline \multirow[t]{3}{*}{$\mathrm{H} 2$} & 0 & $10.3 \mathrm{aA}$ & $10.8 \mathrm{aA}$ & $11.3 \mathrm{aA}$ & $10.1 \mathrm{aA}$ & $10.2 \mathrm{aA}$ \\
\hline & 7 & $10.0 \mathrm{aA}$ & $11.6 \mathrm{aA}$ & $11.9 \mathrm{aA}$ & $11.5 \mathrm{aA}$ & $10.6 \mathrm{aA}$ \\
\hline & 14 & $10.7 \mathrm{aA}$ & $11.4 \mathrm{aA}$ & $11.7 \mathrm{aA}$ & $10.6 \mathrm{aA}$ & $10.1 \mathrm{aA}$ \\
\hline $\mathrm{H} 3$ & 14 & $11.7 \mathrm{aA}$ & $11.0 \mathrm{aA}$ & $11.5 \mathrm{aA}$ & $12.4 \mathrm{aA}$ & $11.7 \mathrm{aA}$ \\
\hline
\end{tabular}

${ }^{\mathrm{z}}$ Harvest intervals: $\mathrm{H} 1, \mathrm{H} 2, \mathrm{H} 3=1,2$, or 3 weeks after vine kill, respectively.

${ }^{\mathrm{y}}$ Fertilizer rates of F-0, F-112, F-224, and F-336 = fertigation rates of 0, 112, 224, or $336 \mathrm{~kg} \cdot \mathrm{ha}^{-1}$, respectively. G-224 = granular application at $224 \mathrm{~kg} \cdot \mathrm{ha}{ }^{-1}$.

${ }^{\mathrm{x}}$ Means within a column (fertilizer treatment) followed by the same small letter at each harvest interval, or by the same capital letter within a row (storage time), do not differ significantly according to Tukey's probability test $(P<0.05)$.

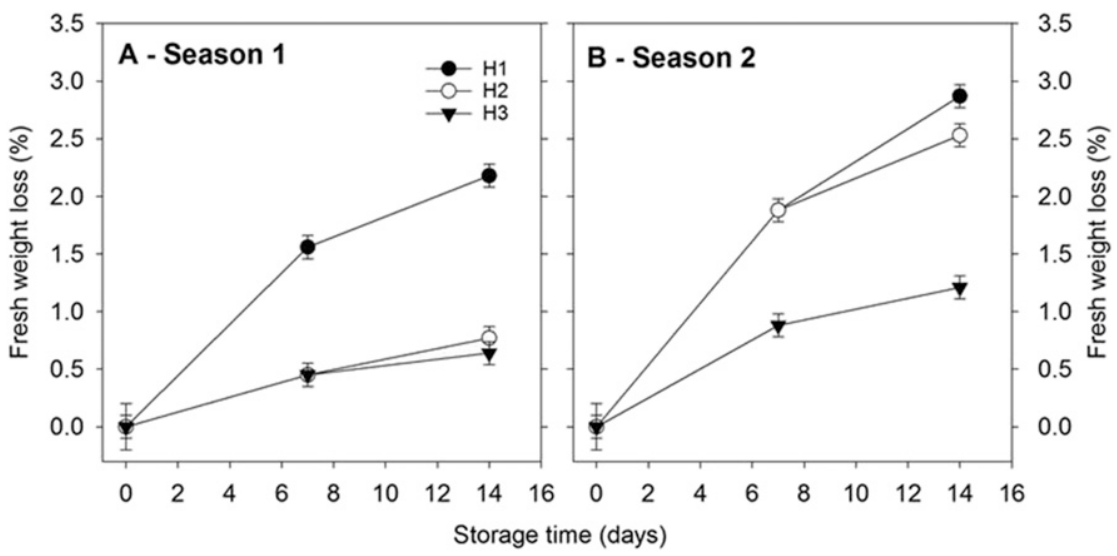

Fig. 3. Effects of harvest interval and storage period on cumulative fresh weight loss of 'Red LaSoda' tubers during $14 \mathrm{~d}$ storage at $10{ }^{\circ} \mathrm{C}, 80 \%$ to $85 \%$ relative humidity by season. Harvest intervals: $\mathrm{H} 1, \mathrm{H} 2$, $\mathrm{H} 3=1,2$, or 3 weeks after vine kill, respectively. Error bars represent standard error at the $95 \%$ confidence interval.

Table 4. Effects of harvest interval and storage period on tuber periderm dry matter content of 'Red LaSoda' tubers during $14 \mathrm{~d}$ storage at $10{ }^{\circ} \mathrm{C}, 80 \%$ to $85 \%$ relative humidity (season 1 )

\begin{tabular}{lccc}
\hline & \multicolumn{3}{c}{ Periderm dry matter content (\%) } \\
\cline { 2 - 4 } & \multicolumn{3}{c}{ Harvest interval $^{\mathrm{z}}$} \\
\cline { 2 - 4 } Storage period (d) & $\mathrm{H} 1$ & $\mathrm{H} 2$ & $\mathrm{H} 3$ \\
\hline 0 & $14.9 \mathrm{bB}^{\mathrm{y}}$ & $14.9 \mathrm{cB}$ & $17.5 \mathrm{aA}$ \\
7 & $17.5 \mathrm{aA}$ & $17.1 \mathrm{bA}$ & $16.4 \mathrm{aA}$ \\
14 & $16.6 \mathrm{aB}$ & $19.6 \mathrm{aA}$ & $16.4 \mathrm{aB}$ \\
\hline
\end{tabular}

${ }^{\mathrm{z}}$ Harvest intervals: $\mathrm{H} 1, \mathrm{H} 2, \mathrm{H} 3=1,2$, or 3 weeks after vine kill, respectively.

${ }^{\mathrm{y}}$ Means within a column (harvest interval) followed by the same small letter at each harvest interval, or by the same capital letter within a row (storage time), do not differ significantly according to Tukey's probability test $(P<0.05)$.

in season 2. Stress on these early-season cultivars grown under F-0 treatment may have been sufficient to interfere with tuber bulking, albeit for different seasons for each cultivar tested (Westermann et al., 1988). Yields were lowest for 'Fabula' and 'Red LaSoda' potatoes grown in F-0 (Makani et al., 2015). Potatoes grown at higher $\mathrm{N}$ rates synthesize and translocate more photosynthates to the tubers, resulting in higher yields (Kumar et al., 2007). Previous studies, where the peel and pulp have not been separated, have shown increased DMC with increased $\mathrm{N}$ rate, up to the point of "overfertilization," with no significant increase thereafter (Kumar et al., 2007; Westermann et al., 1994) or a marked decline (Bombik et al., 2002). Findings from this study suggest that 224 $\mathrm{kg} \cdot \mathrm{ha}^{-1}$ might have been the point of overfertilization, resulting in a decreased rate of dry matter translocation to the tubers during growth. However, weather conditions could have a played a greater role in this as this was observed only during the drier season 2. The extremely heavy rainfall in season 1 likely caused more water uptake into the immature tuber periderm tissue, accounting for the lower periderm DMC at $\mathrm{H} 1$ and $\mathrm{H} 2(14.9 \%)$ than at $\mathrm{H} 3(17.5 \%)$, regardless of NF treatment (data not shown). In the drier season 2, fertilizer treatment and harvest interval had no significant effect on DMC for periderm $(15.0 \%)$ or pulp (15.8\%) for 'Red LaSoda' potatoes.

In both seasons, SSC was significantly lower at $\mathrm{H} 1$ in tubers grown under F-0 (2.98\%) compared with the other fertilizer treatments (3.84\%); SSC was 3.39\% for tubers from $\mathrm{H} 2$ or H3 (data not shown). As mentioned previously, 'Fabula' tubers grown under F-0 had lower
SSC, regardless of harvest interval. Fertilizer treatment, harvest interval or season did not affect tuber AAC (13.6 and $18.1 \mathrm{mg} / 100 \mathrm{~g}$ for periderm and pulp, respectively), TTA $(0.1 \%)$, or $\mathrm{pH}(3.9 \%)$ (data not shown). This may be attributed to an inherent early tuber development and maturation in 'Red LaSoda' tubers, as reported by Zotarelli et al. (2016a).

\section{Potato quality during storage}

'Fabula'. In season 1, cumulative weight loss in $\mathrm{H} 1$ tubers after $14 \mathrm{~d}$ of storage ranged from $3.0 \%$ to $4.4 \%$, compared with $1.2 \%$ to $3.4 \%$ for those from $\mathrm{H} 2$ or H3 (Fig. 1). The significantly higher weight loss in $\mathrm{H} 1$ tubers, regardless of fertilizer treatment, was likely due to poor barrier properties of immature skin to water vapor loss from the pulp (Sabba and Lulai, 2002). Suberin, a complex biopolyester embedded with soluble waxes, is deposited on the periderm during tuber growth and after harvest, minimizing cellular desiccation of the tuber inner tissues (Burton, 1989); suberization occurs at a higher rate with delayed harvest (Tyner et al., 1997). Tubers grown under F-0 had similar cumulative weight loss during storage for the three harvest intervals; however, those from $\mathrm{H} 2$ and $\mathrm{H} 3$ lost more weight during storage $(3.2 \%)$ compared with the other fertilizer treatments $(1.3 \%)$, an indication that the rate of suberin deposition during storage was negatively affected by $\mathrm{N} \mathrm{dep}$ rivation during growth.

In season 2, cumulative weight loss was higher for tubers from $\mathrm{H} 1$ and $\mathrm{H} 2$ (4.4\%) than those from $\mathrm{H} 3$ (2.5\%) (data not shown). The generally drier weather conditions during this growing season may have favored more uniform periderm maturation, regardless of fertilizer treatment. In both growing seasons, tubers had the highest fresh weight loss during the first $7 \mathrm{~d}$ of storage for all harvest intervals, further supporting the negative relationship between weight loss and periderm suberization.

There was no effect of fertilizer treatment or growing season on tuber firmness during storage; tubers from $\mathrm{H} 1$ increased in firmness from an initial of $11.8-13.3 \mathrm{~N}$ at $7 \mathrm{~d}$, then decreased to $12.8 \mathrm{~N}$ at $14 \mathrm{~d}$ (Fig. 2). Gamea 
et al. (2009) attributed the increase in firmness at the beginning of storage to high pulp elasticity resulting from high weight loss. This short-term effect may have been overlooked in other previously published studies with late-maturing potatoes, where firmness decreased during much longer storage periods of 6 to 9 months (Jablonski, 2006). Lower rate of weight loss in the more mature $\mathrm{H} 2$ tubers likely accounted for a significant increase in firmness at $14 \mathrm{~d}$; firmness for $\mathrm{H} 3$ tubers increased slightly after $7 \mathrm{~d}$ storage.

Periderm DMC was initially $10.9 \%$ for tubers from $\mathrm{H} 1$, the least mature tubers, increasing to $13.9 \%$ after $7 \mathrm{~d}$ storage, irrespective of NF treatment or rate, or season (Table 3). Only the F-224 and G-224 treatments decreased after $14 \mathrm{~d}$. Water loss may have concentrated the starch content in cells, which typically constitutes $70 \%$ to $75 \%$ of the DMC (Lisinska and Leszczynski, 1989). There was no effect on periderm DMC for tubers from $\mathrm{H} 2$ or $\mathrm{H} 3$ because of NF treatment or rate, or storage time, similar to results for 'Fabula'. Tuber pulp DMC remained constant during storage $(14.6 \%$; data not shown). Because periderm and pulp tissues comprised very different types of cells, it is likely they reacted differently to the same treatment.

There was no interaction between fertilizer treatments, harvest interval, and storage time on the selected compositional qualities of 'Fabula'; tuber SSC, TTA, and pH averaged $3.59 \%, 0.14 \%$, and $3.86 \%$, respectively (data not shown). AAC was 14.6 and 20.1 $\mathrm{mg} / 100 \mathrm{~g}$ for periderm and pulp tissues, respectively. These results suggest that storage at $10{ }^{\circ} \mathrm{C}, 80 \%$ to $85 \%$ minimized the conversion of starch to sugars during the storage period.

'Red LaSoda'. In season 1, H1 tubers lost the most weight during storage, irrespective of the fertilizer treatment; cumulative weight loss was $2.2 \%$ after $14 \mathrm{~d}$, whereas that for $\mathrm{H} 2$ and $\mathrm{H} 3$ averaged $0.7 \%$ (Fig. 3). There was a similar trend in season 2, although both $\mathrm{H} 1$ and $\mathrm{H} 2$ tubers lost $2.7 \%$, compared with $1.2 \%$ for tubers from H3. Similar to studies with other potato cultivars, delayed harvest permitted increased deposition of suberin waxes in the tuber periderm, thereby minimizing weight loss for tubers from the later harvest intervals. Late-maturing cultivars, however, show increasing weight loss with higher NF rates (Jablonski, 2006).

Tuber firmness in 'Red LaSoda' tubers averaged $12.7 \mathrm{~N}$ throughout storage regardless of fertilizer treatment, harvest interval, or growing season (data not shown). The likely reason was that cumulative weight loss remained $<3 \%$, in contrast to 'Fabula' tubers, which generally experienced higher weight loss and changes in firmness.

In season 1, periderm DMC for $\mathrm{H} 1$ tubers increased after $7 \mathrm{~d}$ storage and remained constant $(17.1 \%)$, whereas that for tubers from $\mathrm{H} 2$ increased to $19.6 \%$ after $14 \mathrm{~d}$ (Table 4). Tubers from $\mathrm{H} 3$ were initially highest in periderm DMC and remained constant during storage (16.8\%), an indication of greater periderm maturity at harvest. In the less rainy season 2, periderm DMC remained constant during storage, averaging $15.4 \%$. This is consistent with the report that less mature tubers transpired more water via the periderm, resulting in higher periderm DMC (Lisinska and Leszczynski, 1989). By contrast, pulp DMC remained constant during storage $(16.8 \%)$ for both seasons, indicating that storage conditions limited weight loss due to transpiration (data not shown).

There were no significant changes in tuber composition during $14 \mathrm{~d}$ storage, for SSC (3.8\%), TTA $(0.2 \%), \mathrm{pH}(4.2)$, and AAC (13.6 and $18.1 \mathrm{mg} / 100 \mathrm{~g}$ for periderm and pulp tissues, respectively (data not shown). This suggests that storage of tubers at $10{ }^{\circ} \mathrm{C}$, $85 \%$ to $85 \% \mathrm{RH}$ minimized oxidative and enzymatic degradation, supporting previous findings for long-term storage studies of latematuring cultivars (Augustin et al., 1975).

\section{Conclusions}

NF application method and rate, and harvest interval affected the tuber harvest quality of early-maturing cultivars 'Fabula' and 'Red LaSoda' grown in spring seasons. Tubers grown with NF rates of $224 \mathrm{~kg} \cdot \mathrm{ha}^{-1}$ or $336 \mathrm{~kg} \cdot \mathrm{ha}^{-1}$ (fertigation only) were generally less compositionally mature at harvest (higher SSC, TTA, and $\mathrm{pH}$ ) than those grown under $112 \mathrm{~kg} \cdot \mathrm{ha}^{-1}$. Both cultivars harvested 1 week after vine kill were less physically mature (less-developed periderm) than those harvested 2 or 3 weeks later. Tuber physical maturity at harvest was a key determinant of storability; tubers harvested 1 week after vine kill had higher losses in tuber quality during $14 \mathrm{~d}$ storage at $10{ }^{\circ} \mathrm{C}, 80 \%$ to $85 \% \mathrm{RH}$ (higher cumulative weight loss and higher pericarp DMC) than tubers harvested later. Tubers from both cultivars grown with NF rates of 112 , 224, or $336 \mathrm{~kg} \cdot \mathrm{ha}^{-1}$ had physical and compositional quality equivalent to those grown with the granular treatment of 224 $\mathrm{kg} \cdot \mathrm{ha}^{-1} \mathrm{NF}$ during storage; best storage quality resulted from tubers harvested 2 or 3 weeks after vine kill.

These results also show the potential to use a lower nitrogen rate $\left(112 \mathrm{~kg} \cdot \mathrm{ha}^{-1}\right)$ with fertigation as a means of improving water and nitrogen-use efficiency, whereas minimizing storage quality losses for these early-maturing potato cultivars grown in subtropical areas.

\section{Literature Cited}

AOAC. 1984. Official methods of analysis of the association of official analytical chemists. The Association of Official Analytical Chemists, Inc., Arlington, TX.

Augustin, J., R.E. McDole, G.M. McMaster, C.G. Painter, and W.C. Sparks. 1975. Ascorbic acid content in Russet Burbank potatoes. J. Food Sci. 40:415-416.

Bombik, A., K. Rymuza, M. Markowska, and C. Startacwicz. 2002. Variability analysis of selected quantitative characteristics in edible potato varieties. Acta Sci. Agr. 6(3):5-15.
Braue, C.A., R.L. Wample, P.E. Kolattukudy, and B.B. Dean. 1983. Relationship of potato tuber periderm resistance to plant water status. Amer. Potato J. 60:827-837.

Burton, W.G. 1989. The potato. 3rd ed. Longman Scientific \& Technical, Essex, UK.

Bussan, A.J. 2003. Physiological processes of potato tuber maturation. Proc. of Wisconsin Ann. Potato Mtg. 16:47-50.

Dahlenburg, A.P., N.A. Maier, and C.M.J. Williams. 1990. Effect of nitrogen on the size, specific gravity, crisp colour and reducing sugar concentration of potato tubers (Solanum tuberosum L.) cv. Kennebec. Austral. J. Expt. Agr. 30(1): 123-130.

Gamea, G., A. El-Maksoud, and A. El-Gawad. 2009. Physical characteristics and chemical properties of potato tubers under different storage systems. Misr. J. Agr. Eng. 26:385408.

Halford, N.G., N. Muttucumaru, S.J. Powers, P.N. Gillatt, S. Hartley, J.S. Elmore, and D.S. Mottram. 2012. Concentrations of free amino acids and sugars in nine potato varieties; Effects of storage and relationship with acrylamide formation. J. Agr. Food Chem. 60:12044-12055.

Iritani, W.M. and L. Weller. 1973. The development of translucent end tubers. Amer. Potato J. 50:223-233.

Jablonski, K. 2006. Effect of nitrogen fertilizer on yield and some qualitative properties of early potato cultivars. Zesz Probl. Post. Nauk. Rol. 511:301-307.

Kumar, D., B.P. Singh, and P. Kumar. 2004. An overview of the factors affecting sugar content of potatoes. Ann. Appl. Biol. 145:247-256.

Kumar, P., S.K. Pandey, B.P. Singh, S.V. Singh, and D. Kumar. 2007. Influence of source and time of potassium application on potato growth, yield, economics and crisp quality. Potato Res. 50(1):1-13.

Lisinska, G. and W. Leszczynski. 1989. Potato science and technology. Elsevier Applied Science Publishers Ltd., London.

Lulai, E.C. and P.H. Orr. 1993. Determining the feasibility of measuring genotypic differences in skin-set. Amer. Potato J. 70:599-609.

Makani, M.N. 2014. Postharvest quality of 'new' potatoes: Effects of improved water and fertilizer use efficiency during production and application of 'rapid curing' during storage. University of Florida, Gainesville, PhD Diss.

Makani, M.N., S.A. Sargent, L. Zotarelli, D.J. Huber, and C.A. Sims. 2015. Irrigation method and harvest time affect storage quality of two early-season, tablestock potato (Solanum tuberosum L.) cultivars. Sci. Hort. 197:428-433.

Manrique, L.A. 1993. Constraints for potato production in the tropics. J. Plant Nutr. 16:20752120.

Mwatuwa, R.Z., C.T. Christensen, P. Solano, and L. Zotarelli. 2017. University of Florida potato variety trials spotlight. Fabula. EDIS Publ. (In press). Horticultural Sciences Dept. UF/IFAS Extension. Gainesville, FL.

Papadopoulos, I. 1988. Nitrogen fertigation of trickle-irrigated potato. Fert. Res. 16:157-167.

Perkins, L.B. 1993. Comparisons of sugars, glycoalkaloids, vitamin $\mathrm{C}$, and organic acids in six potato cultivars from tuber formation throughout storage. Univ. Maine, Orono, ME, Master's Thesis.

Porter, G.A. and J.A. Sisson. 1993. Yield, market quality and petiole nitrate concentration of nonirrigated Russet Burbank and Shepody potatoes in response to sidedressed nitrogen. Amer. Potato J. 70:101-116. 
Pressey, R. 1966. Potato sucrose synthetase: Purification, properties, and changes in activity associated with maturation. Plant Physiol. 44:759-764.

Ranganna, S. 1986. Handbook of analysis and quality control for fruits and vegetable products. McGraw Hill, New Delhi, India.

Rens, L.R., L. Zotarelli, D.J. Cantliffe, P.J. Stoffella, D. Gergela, and D. Fourman. 2015. Biomass accumulation, marketable yield, and quality of Atlantic potato in response to nitrogen. Agron. J. 107(3):931-942.

Reyes-Cabrera, J., L. Zotarelli, D.L. Rowland, M.D. Dukes, and S.A. Sargent. 2014. Drip as alternative irrigation method for potato in Florida sandy soils. Amer. J. Potato Res. 91:504-516.

Sabba, R.P. and E.C. Lulai. 2002. Histological analysis of the maturation of native and wound periderm in potato (Solanum tuberosum L.). Tuber. Ann Bot 90(1):1-10.

Shekhar, V.C., W.M. Iritani, and R. Arteca. 1978. Changes in ascorbic acid content during growth and short-term storage of potato tubers (Solanum tuberosum L.). Amer. Potato J. 55:663-670.

Tyner, D.N., M.J. Hocart, J.H. Lennard, and D.C. Graham. 1997. Periderm and lenticel characterization in relation to potato cultivar, soil moisture and tuber maturity. Potato Res. 40 (2):181-190.

UNECE Standard FFV-52. 2011. Concerning the marketing and commercial quality control of early and ware potatoes. United Nations, New York, NY.

Westermann, D.R., S.M. Bosma, and M.A. Kay. 1994. Nutrient concentration relationship between the fourth petiole and upper-stem of potato plants. Amer. Potato J. 71:817-828.

Westermann, D.T., G.E. Kleinkopf, and L.K Porter. 1988. Nitrogen fertilizer efficiencies on potato. Amer. Potato J. 65:377-386.

Zhang, L., G.A. Porter, and R.J. Bushway. 1997. Ascorbic acid and glycoalkaloid content of Atlantic and superior potato tubers as affected by supplemental irrigation and soil amendments. Amer. Potato J. 74:285304.

Zotarelli, L., P.J. Dittmar, P.D. Roberts, and S.E. Webb. 2015a. Potato production, Chapter 13, p. 233-251. In: P.J. Dittmar et al. (eds.). 2015-16 Vegetable production handbook for Florida. Vance Pub., Lenexa, KS. EDIS Publication HS733.
Zotarelli, L., R.Z. Mwatuwa, C.T. Christensen, D. Gergela, and C.M. Hutchinson. 2016a. University of Florida potato variety trials spotlight: Red LaSoda. EDIS Publ. HS1078. Horticultural Sciences Dept. UF/IFAS Extension. Gainesville, FL. 28 Sept. 2017. <http://edis.ifas.ufl.edu/hs323>.

Zotarelli, L., L.R. Rens, D.J. Cantliffe, P.J. Stoffella, D. Gergela, and D. Burhans. 2015b. Rate and timing of nitrogen fertilizer application on potato 'FL1867'. Part I: Plant nitrogen uptake and soil nitrogen availability. Field Crops Res. 183:246-256.

Zotarelli, L., L.R. Rens, D.J. Cantliffe, P.J. Stoffella, D. Gergela, and D. Fourman. 2014. Nitrogen fertilizer rate and application timing for chipping potato cultivar Atlantic. Agron. J. 106:2215-2226.

Zotarelli, L., S. Sargent, P. Dittmar, and M. Makani. 2016b. Potato vine killing or desiccation. EDIS Publ. HS925. Horticultural Sciences Dept. UF/IFAS Extension. Gainesville, FL. 28 Sept. 2017. <http://edis.ifas.ufl.edu/hs181>.

Zrenner, R., M. Salanoubat, L. Willmitzer, and U. Sonnewald. 1995. Evidence of the crucial role of sucrose synthase for sink strength using transgenic potato plants (Solanum tuberosum L.). Plant J. 7:97-107. 